\title{
The Application of Equity in Brazilian Court Decisions during the Covid-19 Pandemic: Are there any Obstacles?
}

\author{
Anna Lucia Berardinelli * \\ Berardinelli and Meirelles Law Firm-Brazil
}

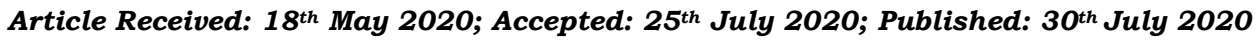

\begin{abstract}
Brazil follows the precepts of the Civil Law system that leaving only limited space for equity. The ongoing pandemic spread crisis and uncertainty worldwide, and there is not enough time for legislators to fill the gaps. Even the already existing legal provisions were designed to cope with unexpected situations, they might be inappropriate in such an unprecedented situation, where everyday contracts are cancelled, obligations are defaulted, companies are bankrupt, and individual rights are mitigated. Courts in Civil Law countries usually do not allow to ground their decisions exclusively on equity powers. This article aims to discuss and propose how the use of evaluative equity in judicial decisions could be the path in the search for the realization of justice, through not only its integrative function but also in an evaluative way, ensure justice in the concrete case. This article concludes that equity is an essential tool for achieving a fair decision and the demands for the common good.
\end{abstract}

Keywords: Brazil; Civil Law Systems; Court Decision; Equity; Covid-19 Pandemic.

How to cite: Lucia Berardinelli, Anna. "The Application of Equity in Brazilian Court Decisions during the Covid-19 Pandemic: Are there any Obstacles?." Udayana Journal of Law and Culture 4, no. 2 (2020): 193-210. https://doi.org/ 10.24843/UJLC.2020.v04.i02.p04

doi: $\underline{\text { https://doi.org/10.24843/UJLC.2020.v04.i02.p04 }}$

\section{Introduction}

In the beginning of civilization, Plato and Aristotle wrote studies that are real legacies on the scope of the word "equity". The concern about the extension of the power granted to judges upon deciding based on equity, however, had already been introduced long before Plato and Aristotle studies.

Maria Fernanda Dias Mergulhão reveals that the concept of equity exists since the early stage of human civilization - the natural state -, in which equity was presented in all decisions, behold, the correspondence between action and reaction was felt in the face of the punitive, correctional, punishing effect that was imposed on conducts disapproved by that social environment. Said concept of equity, though, was open and too broad, often generating injustices since equity was not a rule of exception, but otherwise

\footnotetext{
**Email/Corresponding Author: annalucia@bmcalaw.com.br
} 
applicable to all cases, in an unrestricted and ordinary manner. ${ }^{1}$

The search for the true scope of equity, and the pursuance of the manner equity could be applied to ensure justice in the concrete case dates back to the classical period. Aristotle refined the concepts presented by Plato presenting his definition of equity, in Nicomachean Ethics. ${ }^{2}$ In said work the philosopher expresses that equity is a form of justice, since laws, being theoretical and abstract, should be adapted to the concrete case, with its own set of characteristics and peculiarities. Equity would enable the laws to be better understood, in order to say justice in the best way. Limongi França explains:

"Aristotle's metaphor used to differentiate justice from equity is well known. The philosopher said that the first would correspond to a rigid ruler, while the other would resemble a malleable ruler, capable of adapting to the anfractuosities of the field to be measured. Without breaking the rule (which in Latin is regulated, as, in the same way as a rule), the magistrate, when measuring the equality of specific cases, sometimes finds himself in the contingency of adapting them to unforeseen details and, often, unpredictable by law, under penalty of perpetrating a real injustice and, thus, contradicting the very essential purpose of legal norms." 3

Looking back in history, the Roman Law had its first significant milestone in the application of equity, since the Justinian Code expressly empowered the judge to decide for equity in preference to the jus strictum. In medieval law, St. Thomas Aquinas developed the concept of equity proposed by Aristotle under the Christian bias. He bequeathed to the world the work entitled "Summa Theologiae." 4

In new civilizations, the existence of the legal status and the status of legality, prevails. Therefore, equity would be an exception and could only be applied if previously disposed of by the legislator. The stability of social relations that became more recurrent, as the decision must be based on the law, and not on an abstract concept of natural justice, submitted to the backgrounds of those making the decisions.

This is the interpretation that prevails in the legal systems that follow the precepts of the Civil Law System, such as Brazil. Brazil does not officially adopt a system of binding precedent in which its legal system and procedure remain base on the civil law tradition. ${ }^{5}$ The Brazilian legal system uses the "súmulas" to standardize precedents, a type of summary of leading

\footnotetext{
${ }^{1}$ Maria Fernanda Dias Mergulhao, "O principio da Equidade: por uma nova exegese," Gen Jurídico, 21 July 2017.

2 See Aristóteles. Etica nicomachea. Milano: Bompiani, 2003.

${ }^{3}$ R. Limongi França. Hermeneutica Jurídica (Sao Paulo: Saraiva, 1988),71.

${ }^{4}$ Maria Fernanda Dias Mergulhao, loc.cit.; Santo Tomás de Aquino. Summa theologiae: cura fratrum eiusdem ordinis. (Matriti: Biblioteca de Autores Cristianos, 1952).

${ }^{5}$ Evan Rosevear, "Social Rights Interpretation in Brazil and South Africa (Interpretação de direitos sociais no Brasil e na África do Sul)," Revista de Investigações Constitucionais 5, no. 3 (2018): 171.
} 
jurisprudences, which has a binding effect. ${ }^{6}$

Understanding the real meaning of the word "equity" is of utmost importance, since, based on its genesis, equity was conceived as an open and imprecise concept due to its very nature. The review of the expression "equity" from the most diverse angles (cultural, historical, economical, etc.) is imperative, since equity is a word with plural significance, generating numerous divergences in doctrinal and jurisprudential grounds. Part of the doctrine refers to the concept of Luis Recaséns Siches, which maintains that equity would be superior to the legal "just", since equity is an expression of the natural just, which means that the legal just would be in fact detached from the words of the law, if not synced with the just in relation to the specific case. ${ }^{7}$

The judge could then decide according to his prudent discretion, when he considered the application of the legal text unacceptable or that the outcome would be unreasonable. There are other positions, which say that equity would be a recourse to insufficiencies in the legislation, used to fill regulatory gaps, or even to clarify open statements.

Other positions refer to equity as the capacity of adaptation of abstract legal statements to the circumstances or factual requirements of the specific case, according to certain criteria. Equity is inherent in the mechanism of legal interpretation, which would always impel the interpreter to adopt reasonable exegesis, in tune with common sense and accepted, without disgust, by human reason.

In this perspective, it is not exactly a decision for equity, but a decision handed down according to equity. See the excerpt below providing Streck-Delfino's conclusion: ${ }^{8}$

"The judge would be prevented from departing from the positive law, nor could he correct or rectify the law, since his purposes, although noble, would not be sufficient to authorize him, from his own voluntarism, to shape the result of his decisions, to reach its own idea of justice. This latter position seems a little better, although it is not known what such reasonable exegesis would be."

Based on this unquestionable divergence, some authors, such as Carlos Maximiliano states there are guidelines in the sense that equity is not a vehicle for the protection of minor and obscure interests. Equity should be used only to attenuate the rigor of a text and interpret it in a way that is consistent with human progress and solidarity: ${ }^{9}$

“...it will never be the same invoked to act, or decide, against a clear and foreseen positive prescription. This caveat, moreover, is

\footnotetext{
${ }^{6}$ Lucas Alves Edmundo Gomes, "The Influences of Common Law on the Brazilian New Code of Civil Procedure," International Journal of Legal Information 46, no. 3 (2018): 176-180

${ }^{7}$ Streck, Lenio Luiz and Lúcio Delfino. "Novo CPC e a decisão por equidade: a canabalização do Direito." Consultor Jurídico, 29 December 2015.

8 Ibid.

9 Carlos Maximiliano. Hermeneutica e Aplicação do Direito (Rio de Janeiro: Forense, 2003), 142.
} 
less important today than it would have been in the past: first, since the prestige of the brocardo has disappeared - in claris cessat interpretatio; second, since, if in other times the possible result of an exegesis avoided absurdity, excessive harshness or evident injustice, today, with the victory of the doctrine of the socialization of Law, more than ever the hermeneutic he despises fiat justitia, pereat mundus- and is guided by the likely consequences of the decision he coldly reached."

As a matter of fact, it is impossible to provide laws for all conducts that deserve legal treatment. As a matter of fact, in any legal system, this attempt, if accomplished, will fail, since the human being, who is mutant, in their essence, will reveal a new condition or particularity, which has not been previously foreseen. Furthermore, life is always full of surprises and unthinkable circumstances, such as the one we are experiencing right now, with the Covid-19 pandemic. Thus, the use of equity as a way of doing justice to individual cases is mandatory.

Considering this apparent contradiction as a motivation, it is necessary to examine in this article how traditional positivism provided a poor treatment to the issue, and, on the other hand, reviewing the answer provided by classical jus naturalism, analyze the way this line of thought proposes to solve the issues involved derived from the tension between the general law and the specific case.

The motivation consists of what has been provided by Aristotle in Nicomachean Ethics: since the distance between the general rule, established by the legislator in view of what ordinarily happens, and a particular event that, nevertheless being formally included in the words of the legal text, be so specific that it moves away from that common situation, that the legislator took into account when drafting it.

In fact, many situations in real life could not be anticipated by the legislator. Therefore, if said situations have not been taken into account by the law operator, this situation will lead to severe injustices.

The most considerable difficulty is not to define what equity is accurately, but demonstrate when and why equity should be applied in a normative system, like the Brazilian system, which follows the precepts of the Civil Law. Actually, the Civil Code and the Civil Procedure Code have expressly provided that the application of equity is minimal, as we will discuss below.

Even academically, most Brazilian Legal Scholars and the highest Brazilian Courts consider that equity should only be applied whenever it is foreseen by law. The following is an example related to Tax Law, which provides that equity should not prevail to the detriment of law:

"In the "inter-vivos" property transfer, tax takes according to the appealed arrest. Extraordinary appeal that should be dismissed, since paragraph 3, of art. 23, of the Constitution of the Brazilian Republic, has not been the subject matter of assessment by the decision then rendered (Summary 282 and 356). Otherwise, the 
appealed decision was based on the State legislation and, referred to paragraph 2, of art. 108 of the Tax Code, according to which "equity cannot be evoked to avoid the due tax requirement. Reasonable interpretation of the Federal Law (Sum 400). Finally, no case-law controversy has been proven (SUM 291)." 10

The example above shows the force and power of written law in Brazil, which adopts the Civil Law System, enforcing the law for justice in many hard cases. The reality in Brazil is that equity is mostly allowed only in its integrative function, filing existent gaps.

On the other hand, in some very emblematic cases of the Brazilian Supreme Court, decisions are based mostly on equity. In ADPF 54, the famous case involving the right to abortion in case of anencephaly of the fetus, the woman's mental health has acquired a more extensive protection scope, under the argument that the science of anencephaly, considering the pregnant woman, generates psychological disturbance at a high degree, and, therefore, the pregnant woman's interests must prevail over the right to life of the fetus as a constitutional value.

The review of some parts of this trial shows the rhetorical exercise, by the amicus curiae, to pursue what is known as "just", as in jusnaturalism, by justifying the result in the classic Brazilian literature, or religious beliefs and feelings, to suppress the application of written law, which forbids abortion in Brazil:

"[...] Although there are other people involved in this case, the pregnant woman is the person who suffers more, since the anencephalic fetus is an event in her body. The pregnant woman, in this case, will not even become a mother, since there is and there will not be any child. By forcing women to keep a fetus that is going to die, or that is already technically dead, the State and society interfere with her right to bodily integrity and to make decisions about her own body. In the case of healthy fetuses, the discussion on whether the woman is obliged to have the child can be carried out, as the fetus will become a person and, therefore, the life of the fetus is entitled to preservation."11

Justice Carmem Lucia, one of the 11 justices of the Brazilian Supreme Court, provided her opinion:

"Anyone (who doesn't even need to have read legal literature), who has had the opportunity to read "Manuelzão e Miguilim", by

\footnotetext{
10 Brazilian Supreme Court. RE 111027, Judging Panel: $2^{\text {nd }}$ Panel - Rappoteur: Justice Djaci Falcao, Trial, 1986.

11 Speech by doctors Telma Birchal and Lincoln Frias in public hearings transcribed in the Action for Breach of a Fundamental Precept number 54 (ADPF Report 54). The English version, among others, can be read in Lúcia Gonçalves de Freitas, "The STF Decision on Abortion of Anencephalic Fetus: A Feminist Discourse Analysis," Alfa: Revista de Linguística (São José do Rio Preto) 62, No.1 (2018):26.
} 
Guimarães Rosa, knows that perhaps the most exceptional example of human dignity, that God has conveyed to us, was precisely that of the mother - and look, I have a super dad! The mother's dignity goes beyond herself, beyond her body. When Guimarães Rosa puts the woman in her arms carrying a dead son, who had damaged a little piece of cloth on her little foot a few days before, she seeks to bathe the dead son's small body and almost bumps into the basin; she then ensures that, even though the child is dead, she doesn't have any bumps since it would be suffering imposed on that little body. Anyone who has read it, will know that when a mother decides to interrupt a life (for a moment or life for another month), this is not an easy choice, but otherwise a tragic choice always; this is a choice that is made to continue and not to stop; This is the choice of the possible in a complicated situation. Therefore, I think it is necessary to know that all options like this, even this interruption, are painful. The choice is the least pain; This aims not to hurt, since the pain of living has already occurred, as well as the pain of dying. This only enables the choice in that sense." 12

The examples above demonstrate that equity is applied only exceptionally in Brazil, and in very emblematic cases. Even in those cases, a great argumentative effort (even mentioning literature) is required to fight the sharply raised positivist view. This is a big challenge in a very hermetic Civil Law System, such as the Brazilian Civil Law System, which is strongly associated with the written norm.

Equity is also generally understood as the body of norms developed by the Court of Chancery or Court of Equity (like the trust, the injunction, etc) and regarded as a judge-made law developed in parallel to the Common Law. ${ }^{13}$ It may be assumed that that only by some kind of symbiosis between the Civil Law System and the Common Law System, ${ }^{14}$ balancing the extremes of each system, a broader application of equity would be possible.

The present article, is written in light of the current health and economic crisis that are affecting the world. It aims to discuss and propose how the use of evaluative equity in judicial decisions could be the path in the search for the realization of justice, through not only its integrative function but also in an evaluative way, ensure justice in the concrete case. This article focuses on some legal and practical challenges as described above. Besides, it explores the principle of equity, since equity is the adjustment of the law to the real case through the analysis of the relevant characters of the said case), and the spectrum of power distributed to courts in Civil Law tradition, particularly in the Brazilian legal system. This

\footnotetext{
12 Brazilian Supreme Court. ADPF 54 - Opinion of Justice Carmem Lúcia,

13 Anne-Françoise Debruche, "What is "Equity"? Of Comparative Law, Time Travel and Judicial Cultures," Revue générale de Droit 39, no. 1 (2009): 223

${ }^{14}$ Court equity power are practiced in common law countries, such as the United States of America. See for example in the writing of Kristin A. Collins, "A Considerable Surgical Operation": Article III, Equity, and Judge-Made Law in the Federal Courts," Duke Law Journal 60, no.2 (2010): 249-343.
} 
research also seeks to demonstrate the relevance and importance of the definition of Equity to the sense of Justice, and how the practical application of Equity proves to be an indispensable tool for the State to the efficient delivery of justice through judicial decisions, thus fulfilling its social function.

This paper used the inductive research method, relying on the review of the written law, and very recent court decisions related to the subject. The approaches in this research are the historical approach, comparative approach, and the conceptual approach. It examines the background of what is being studied and the development of the legal issues at hand, and assess the issue based on a historical approach. The conceptual approach departs from the views and doctrines in legal studies. The legislations used as the primary legal materials in this paper are, among others, the Constitution of the Republic of Brazil of 1988, the Brazilian Code of Civil Procedures, and the Brazilian Civil Code. Besides, it utilizes some academic papers, journal articles, and court decisions.

\section{Result and Discussion}

Civil Law System generally puts some limitations to the application of equity. In the Brazilian case, those limitations are expressed in the Civil Code and Civil Procedure Code, which provide that equity should only apply when there is no legal norm applicable to the case, or when the law specifically authorizes it.

This analysis initially requires, however, the investigation of the content of the word equity, subdividing it in its evaluative and integrative forms.

\subsection{Evaluative Equity and Integrative Equity}

Equity is a powerful tool used to interpret the law, assisting judges who seek to approach the ideal application of justice and apply a general rule to the specific case. The following is an excerpt of Silvio Venosa's lesson on the matter:

"Equity is not only the softening of the norm in a specific case, but also a feeling that derives from the judge's heart. Since its concept is philosophical, it gives rise to several conceptions. (...). Let us understand, however, that equity is a philosophical idea, above all; and that each law enforcer will carry out its own assessment, but with the same purpose of easing the norm. Undoubtedly, there is a lot of subjectivity of the interpreter in its use. ${ }^{15} "$

This is similar to Aristotle's solution to the apparent dichotomy between the just and the equitable. Equitable is indeed fair, but not according to the law. Equity is, actually, a correction of the just established by law, to the point that it is defective due to its generality. Although the law

15 Silvio de Salvo Venosa. Direito Civil (Sao Paulo: Atlas, 2001), 47. 
is a universal norm, the law cannot deal universally with particular cases ${ }^{16}$. Klaus Cohen-Koplin agrees with this understanding as follows:

"Equity, therefore, does not imply any kind of revolution by the enforcer against the law, but a real insistence on the preservation of its legitimate field of autonomy and incidence." 17

Based on this aspect, we have equity in its evaluative form, which is a broad concept that can present itself in several aspects, such as the question of 'social function of the norm'.

Therefore, when applying the evaluative equity, the legal analysis will be filed with equity as an ideal of justice, but the ruling will still be based on formal and written law. See, in this regard, the lesson by Justice Fux, one of the most brilliant justices among the 11 justices of the Brazilian Supreme Court:

"Substantially, the judge, when deciding the merits, must adopt the "solution that he considers most fair and equitable, taking into account the social goals of the law, and the requirements of the common good. In this regard, the law, using legally indeterminate concepts, authorizes the judge to reverse the old syllogism and adopt the just solution and then adorn it with the legal rule applicable, in the light of equity and the requirements of the common good. The judge must take into consideration not only the letter of the law, but the environment in which the law will be applied, shaping the law to the new realities, without however being authorized to decide against legem. This rule in lawsuits works to its fullest when there are gaps in the law." 18

Even in the Civil Law system, there are no significant controversies regarding the application of equity in its evaluative form, since the judge is still attached to the legal text, and the pursuit of justice as an ideal is always something desirable.

However, the most significant controversies arise when we analyze equity in its integrative form. Moving forward, we must still examine the integrative form of equity, due to its subdivision into two functions: integrative and corrective.

The first function would rise in the absence of law, that is, a gap, where the judge does not find any law applicable to the concrete case. The second function results from the fact that the existing law is so significantly unjust concerning the concrete case, that the judge finds no other solution than applying equity to the case.

Regarding the integrating function, Sergio Cavalieri Filho, former

16 Aristóteles. Etica nicomachea. op.cit.

17 Cohen-Koplin, Klaus. "Equidade e Razão Prática na decisão judicial: Algumas reflexes de Teoria Geral do Direito e de História do Pensamento Juridico." Revista da Faculdade de Direito da UFRGS 28 (2011)

${ }^{18}$ Luis. Fux, Curso de Direito Processual Civil. (Rio de Janeiro: Forense, 2001), 480. 
President of the Court of Justice of the State of Rio de Janeiro, and eminent legal scholar, teaches as follows:

"According to Aristotle, equity has an integrating and corrective function. The first takes place when there is a void or gap in the law, in which case the judge can use equity to resolve the case, without reaching the point of creating a rule, as if it were the legislator."19

The idea behind the integrating function is that based on the circumstances of a given case, the judge could reach a conclusion, tailored to that specific case, almost as the legislator, himself, could have foreseen the situation, and been aware of the case.

Regarding the corrective function, Minister Ruy Rosado, former Justice in Brazilian Superior Court of Justice, clarifies:

“(..) However, this equity, which Aristotle refers to in his work Nicomachean Ethics, is the corrective equity, the equity that the judge will apply when he needs to avoid an injustice that would result from the strict application of the law." 20

After discussing the different forms and functions of equity, we must stress that the Brazilian system, as a system that follows the precepts of the Civil Law, generally speaking, does not allow the unrestricted use of the integrative equity, but admits, however, without significant controversies, the application of equity in its evaluative form. The matter is far from being definitively settled, as demonstrated in the other sections of this article.

\subsection{Equity and the Brazilian Legal System}

The Brazilian legislation brings several examples of equity, in all its meanings already analyzed in this article. Thus, the sense of equity in Brazilian legislation may vary depending on the legal context in which equity is provided.

But even if equity was provided for in the written norm, some legal provisions generate doctrinal controversy on the subject. provides that equity is admitted in the Brazilian Code of Civil Procedure in an unusual way, and upon prior law authorizing its application. It says that "The judge will only decide based on equity in the cases provided for in law."21

The Law of Introduction to the Rules of Brazilian Civil Law (LICC) provides that the application of the law, given "the social purposes to which the law is directed and the requirements of the common good" does not constitute an expression synonymous with equity, except in the conception that was expressed as evaluative equity. This is transcribed in Article 5 of

\footnotetext{
${ }^{19}$ Ruy Rosado apud Carlos Alberto Menezes Direito and Sérgio Cavalieri Filho, Comentários ao novo código civil. Volume XIII (arts. 927 a 965), Da responsabilidade civil, das preferências e privilégios creditórios (Rio de Janeiro: Ed. Forense, 2004), 335. 20 Ibid.

${ }^{21}$ Article 127 of the Brazilian Code of Civil Procedure/ Código de Processo Civil (CPC)
} 
LICC as follows: "Upon applying the law, the judge will serve to the social purposes to which the law is directed and the requirements of the common good." The same law actually gives room to the integrative equity, as stipulated in Article 4 LRNB, as follows:" When the law is silent, the judge will decide the case according to the analogy, customs and general principles of law."

Therefore, based on the two first examples, it is obvious that evaluative equity is present in Brazilian legislation, and judges are authorized and encouraged to apply it. This is what we can observe, for example, in the cases related to access to health care, and the obligation to provide free and universal health care, that is established in the Brazilian Constitution. In that kind of law case, when the demand is to force the State to provide the health care, usually the Courts base their decisions not only in the constitutional obligation, but also in evaluative equity, to justify that the eventual lack of resources from the State, could not justify the denial of a right.

This view is clearly provided in the following excerpt from an award rendered by the Supreme Court in a case that has become a reference, and is often repeated with approval in subsequent decisions:

"Between protecting the inviolability of the right to life, which qualifies as an undisputable individual right ensured by the Constitution of the Republic itself (art. 5, caput), or making a financial and secondary interest of the State prevail against this fundamental prerogative, I understand - once this dilemma is configured - the ethical-legal reasons imposed on the judge, with one and only possible option: the undeniable respect for life." 22

But the main problem regards the third example, and the understanding of whether equity could be considered a general principle of law, or not. There is plenty of controversy regarding the subject.

Despite the doctrinal controversies, the idea that prevails is that equity is not present in Article 5 of the LRNB, since that would be only a generic recommendation to serve the common good. Also, the majority of the doctrine understands that Article 4 above would not be an example as well, since equity does not constitute an analogy, custom or general principle of law. In that sense, the doctrine of Silvio Rodrigues explains the following:

"Strictly speaking, the judge cannot judge based on equity, since the solution based on equity is only admissible when the law expressly allows its application (CPC, art.127). So, given the case in the example, either the judge considers the action to be wellfounded and sentences the agent that caused the damage to the payment of the full indemnity, or if the judge understands that the indemnity represents excessive punishment for such a slight fault, the judge will dismiss the suit. In this case, hereunder, the indemnity cannot be set at half, or based on any other proportion,

${ }^{22}$ RE 271.286 AgR- RS, Rapporteur Justice Celso de Mello 
since the judge cannot decide a case based on equity. ${ }^{23}$ "

Regarding Article 4, Maria Fernanda Dias Mergulhão refers to the doctrinal dissent on the functions of equity in her doctrinal article, as follows:

"Maria Helena Diniz points out that Article 5 of the Introduction Law establishes equity as an element of adaptation and integration of the rule to the particular case, explaining that equity is the capacity of the legal norm to mitigate its rigidity, adapting to the current case. In its new role, equity does not intend to break the norm, but otherwise to extend equity to the social and -evaluative circumstances of the concrete fact at the moment of its application. After all, Aristotle's respected definition of equity is that the justice of the specific case is repeated. ${ }^{24}$

Therefore the Brazilian law provides that, equity can only be applied in its evaluative form, or in the cases expressly provided for by the legislator, in spite of all the controversies already demonstrated in this paper.

As an example, we can mention this decision from the Federal Court of Justice of Rio de Janeiro literally providing that equity could not be applied to avoid the enforcement of the tax law, even if the situation was unfair:

"Tax. Decree-Law No. 2434/88. Tax on financial transactions as tax on exchange transactions. Concerning an import slip, issued previously to July 1988, however, with the exchange transaction closed at a later date - 1. Article 6 of Decree-Law No. 2434/88 is exempted from IOF payment only in relation to import slips issued from $7 / 1 / 1988$ on, and this provision is not applicable to slips issued before that date. 2. No standard (CTN art. 176), in spite of all the controversies already exposed, as for mere equity, exempt from paying the tax (CTN art. 108, paragraph 2). 3. Unanimously grant of appeal and reference" 25

Therefore, given the exceptional nature of its application, in order to respect the tripartite system of State functions, the equity should be applied exclusively when such an application is expressly allowed in the written norm.

\subsection{Equity in Common Law and Civil Law Systems}

The idea of equity is different in the two major legal systems used worldwide. Due to its own codified and written nature, the Germanic Roman system leaves much less scope for the judge upon rendering a decision, limiting the application of equity in its integrative dimension. In the

\footnotetext{
${ }^{23}$ Silvio Rodrigues. Responsabilidade Civil. V. 4. 20a ed (Sao Paulo: Saraiva, 2008), 188.

${ }^{24}$ Maria Fernanda Dias Mergulhao, loc.cit.

25 TRF 2 Region. Second Class, AMS 90.02.13999-3. Rio De Janeiro. Judge Luis Alberto Nogueira. 1992.
} 
Common Law System, where the court precedent is deemed a "law", the opposite situation occurs.

However, as Márcio Ribeiro Borges teaches, the modern world does not allow us to think of two undisputable and foreign systems, since one of them is now clearly influenced by the other:

However, this distinction entails the presence of two hermetic systems, foreign to each other and prone to mutual exchanges, as if there were a dichotomy, a mutual exclusion, with the use of an importing in the adhesion to a specific order that excludes the application of legal norms that are characteristic of the other system."

In the same sense, the author quotes Miguel Reale, for whom both systems:

“(...) these are diverse cultural expressions that, in recent years, have been the object of reciprocal influences. While legal norms gain more and more importance in the common law regime court precedents play an increasingly important role in the Law that follows the Romanistic tradition." 26

This connection between the two systems, which are continually improving, based on the lessons that they exchange with each other, has been the current stimulant. This event has also been noticed in the Brazilian law, such as, for example, in the provisions brought by the updated version of Brazilian Code of Civil Procedure, which is in force since March 2016. It has a very different structure to its predecessor. This new Code divided into the general part and the special part and ends with a book titled "final and temporary provisions." 27

The Brazilian law is based on the Roman-Germanic system, and the prominent position of the law in the civil law system can be clearly seen in the current Brazilian legal system, and provided literally in Article 5 of Brazilian Constitution of 1988:

"All are equal before the law, without distinction of any nature, guaranteeing to Brazilians and foreigners residing in the Country the inviolability of the right to life, freedom, equality, security and property, in the following terms:

(...) II - no one will be obliged to do or fail to do anything except under the law;

However, as Márcio Ribeiro teaches the Brazilian legal world has long been influenced by countries that traditionally adopt common law, notably the United States, being certain, for example, that the political organization

\footnotetext{
${ }^{26}$ Miguel Reale. Lições Preliminares de Direito. 25.ed (São Paulo: Saraiva, 2000), 146.

27 Teresa Arruda Alvim Wambier and Cassio Scarpinella Bueno, "Civil Justice in Bazil," Brics Law Journal 3, no. 4 (2016): 10.
} 
of the Brazilian State, since the proclamation of the Republic, is firmly based on the North American, not only in the Judiciary, but also in the Legislative and Executive branches. 28

Based on abundant legal doctrine, and countless examples already brought into the legislation, it is possible to conclude that the mixture carried out in the country has even resulted in a kind of hybridism between both models. Therefore, contrary to what most of the doctrine advocates, a solution would be adopting a less tight view, in the search for the ideal of justice.

This could represent an evolution to the Brazilian legal system, as shown in the legal provision of Article 4 of the LICC on the application of equity in its integrative expression.

\subsection{Equity and Covid-19}

The current situation, unprecedented in recent history, has brought numerous challenges to courts worldwide, which will not find a just solution for the specific cases under examination if decisions are not based on the equity in its both forms: evaluative and integrative.

The analysis of the current scenario allows us to conclude that the court decisions, during the Covid-19 pandemic, should have a more pacifying nature, seeking the most equitable solutions to the specific case. This is already being accomplished in many civil cases, such as the ones asking for a revision of rentals, or reimbursement for airplane tickets or hotel reservations, payment of child support, and even requests for bankruptcy. In all those types of cases, and others, the decisions are being mitigated by equity, under the allegation of the extreme burden caused by the Covid-19 pandemic. The imposition of an extraordinary burden on the parties is not reasonable at a time when everyone is excessively already burdened. This is the kind of sensibility required from judges when applying the rule of law.

A decision that is not consistent with the current scenario, as Frederico Cortez explains in a recent article on the subject, would be on a "collision course with the principles of reasonableness and proportionality." 29 The author deftly states that he does not advocate disobedience to the law, but a new justice in the light of this coronavirus pandemic. He further states: "A faster, less conflicting and more aligned court, in its broad sense."

We fully agree with the aforementioned author, and also add that a broader view of the concept of equity, starting to see equity as a general principle of law, as provided for in Article 4 of the LICC, could guide the path of magistrates in this current obscure scenario.

\footnotetext{
${ }^{28}$ Márcio Ribeiro Borges and Thais Vandresen, "Common Law e o Novo Código de Processo Civil: Teoria dos Precedentes Vinculantes e outras Influencias," Anais do Congresso Catarinense de Direito Processual Civil (2015)

${ }^{29}$ Frederico Cortez, “A Nova Justiça Com o COVID-19.” Focus.Jor. 20 March 2020.
} 


\subsection{Some Recent Legal Cases}

As the Pandemic spreads throughout the country, causing shocking waves of death and poverty, Brazilian Courts are being flooded with lawsuits that require interpretations that go beyond of what the legislators could predict.

The Brazilian legislation 30 and the case-law, for example, clearly provides that the Public Electric Companies have the regular right to interrupt the service in case of failure to pay the energy bills. This has been the norm in many decisions, such as the one transcribed below :

"APPEAL. Legal consumption relationship. Electricity supply contract. Service interruption based on debt. Refusal to restore electricity based on past debt due to irregularities found through TOI - Occurrence and Inspection Report. decision, declaring the financing contract null and void, eliminating the alleged debt in the amount of $R \$$ 1,668.30. Dismissal of the compensatory claim. (...) Reviewing the sensitive elements collected during the procedural march, the plaintiff's claim to attribute to the conduct of the defendant company an immeasurably severe range, which is not consistent with the scenario shown in the case file, showing its intention to overestimate the consequences arising from the facts described by the consumer. Actually, the interruption of the provision of the service in question proved to be lawful, since the interruption was justified by the existence of a defaulted debt." 31

More recently, in the face of the new reality brought by the pandemic and all the economic impact caused by it, this line of the decision would not be consistent with equity. Until Energy Regulatory Agency (ANEEL) published a resolution on the subject, judges faced a hard situation with those claims of suspension of electric service, since there is a small room for decisions based exclusively on equity in the Brazilian legal system. However, after the issuance of ANEEL's Resolution 878/20, the case-law changed, and the courts started to ground the decisions that did not allow the suspension of the service on this new regulation.

That was what happened in another recent case, when the President of the Court of Justice of the State of Rio de Janeiro, Justice Claudio de Mello Tavares, denied the request for reconsideration filed by Light's (Public Electricity Company), and upheld the decision to prohibit the concessionaire from interrupting the supply of electricity for non-payment during 90 days ${ }^{32}$ :

"Although the interruption of the energy service is, in principle, a regular exercise of rights, the interruption of the supply of

\footnotetext{
${ }^{30}$ For example Article 2, III, of Resolution 878/20 from Energy Regulatory Agency ( ANEEL) 31 Tribunal de Justiça do Estado do Rio de janeiro. Appeal. 0448758-88.2010.8.19.0001. Des. Murilo André Kieling Cardona Pereira -Trial, 2018.

${ }^{32}$ Poder Judiciario, Estado Do Rio de Janeiro, "Presidente do TJRJ nega recurso da Light e mantém proibição de corte do fornecimento de energia elétrica pelo prazo de 90 dias," Notícia publicada por Assessoria de Imprensa em 14/04/2020.
} 
essential services must be avoided during the 90-day period, indicated both in ANEEL Resolution and in State Law No. 8.769 of 2020 , in compliance with the constitutional principles of the intangibility of the dignity of the human person, and the guarantee to health and life, without prejudice to the adoption, by the concessionaire, of other measures provided for in law for the collection of likely debts.

There is also another example from the same Court, in the same sense:

“(..) decision that denied the restoration of the supply of electricity in consumer unity. Appeal to the author adducting that the suspension of the essential service complies with the State law number 8769/2020 and the normative Resolution of ANEEL number 878/2020 that imposed the public service concessionaire the suspension of the charges and the duty of the ownership. Electricity supply. With effect, present in the strength hypothesis the requirements elected in art. 300 of $\mathrm{CPC} / 2015$. State Law number $8769 / 2020$, when provisions on protection to the Fluminense population during the contingency plan of COVID-19, prohibited the suspension of essential services for lack of payment. (...) In the same sense, ANEEL normative resolution n. 878 edited. Decision that deserves reform to determine that the defined concessionaire shall absence from suspending the service for non-paid bills in from January to March 2020, in addition to those which exceed while the contingency measures last. Partial provision of the appeal. ${ }^{33}$

Thus, although the interruption of the energy service constitutes, in principle, a regular exercise of rights, the interruption of the supply of essential services must be avoided during the 90-day period. This is indicated both in ANEEL Resolution and in State Law No. 8.769 of 2020. All in compliance with the constitutional principles of the intangibility of the dignity of the human person and the guarantee to health and life, without prejudice to the adoption, by the concessionaire, of other measures provided for in law for the collection of debts.

The above-mentioned cases show that Brazilian Courts are grounding their decisions on new regulations, contrary to the previous existing law. However, they are also basing their decisions on equity, and constitutional principles, to make sure that justice is being applied in the concrete case. This allows social justice and peace to be sustained during such a severe and unprecedented crisis.

33 Tribunal de Justiça do Rio de Janeiro TJ-RJ - Agravo de Instrumento : AI 00189618620208190000 - Inteiro Teor, Des (A). Sandra Santarém Cardinali, Trial, 2020. 


\section{Conclusion}

Considering all the issues analysed from a Brazilian law perspective, it can be concluded that equity is an essential tool for achieving a fair decision and the demands for the common good.

Through its application, the abstraction of the legal norm is eased, allowing the delivery of justice to meet the intentions of the disputing parties, putting an effective end to the dispute. Of course, based on the perspective of the effectiveness of the jurisdictional provision, a fair and equitable decision is the most appropriate solution to the legal case brought before the Court.

The judges' mission is tough and complicated, since, acting as a political agent of social pacification, in addition to the mastery in the knowledge of the litigious facts, as well as the corresponding legal framework to be applied, he must bear in mind the need to deliver the jurisdictional provision fairly and equitably, in order to achieve social justice.

It seems that the legislator is unable to predict all the nuances of real life, with all the unpredictability of its concreteness. If any staunch positivist dares to doubt this, the current Pandemic beats any stir.

The judge is not, and should not be deemed, a machine devoid of evaluation capacity, and without any scope for adapting the law to the specific case. It is precisely on this margin that equity is required and expresses itself. Therefore, considering the importance of equity, and its use by judges (mainly during this Covid-19 Pandemic) will lead to a higher quality legal service, which meets the real social concerns of justice.

\section{Book}

\section{BIBLIOGRAPHY}

Aquino, Santo Tomás de. Summa theologiae: cura fratrum eiusdem ordinis. Matriti: Biblioteca de Autores Cristianos, 1952.

Aristóteles. Etica nicomachea. Milano: Bompiani, 2003.

Direito, Carlos Alberto Menezes and Sérgio Cavalieri Filho, Comentários ao novo código civil. Volume XIII (arts. 927 a 965), Da responsabilidade civil, das preferências e privilégios creditórios. Rio de Janeiro: Ed. Forense, 2004.

França, R. Limongi. Hermeneutica Jurídica. Sao Paulo: Saraiva, 1988.

Fux, Luis. Curso de Direito Processual Civil. Rio de Janeiro: Forense, 2001.

Maximiliano, Carlos. Hermeneutica e Aplicação do Direito. Rio de Janeiro: Forense. 2003.

Reale, Miguel. Lições Preliminares de Direito. 25.ed. São Paulo: Saraiva, 2000.

Rodrigues, Silvio. Responsabilidade Civil. V. 4. 20a ed. Sao Paulo: Saraiva, 2008.

Venosa, Silvo de Salvo. Direito Civil. Sao Paulo: Atlas, 2001.

\section{Journal Article}

Borges, Márcio Ribeiro and Thais Vandresen. "Common Law e o Novo Código de Processo Civil: Teoria dos Precedentes Vinculantes e outras Influencias." Anais do Congresso Catarinense de Direito Processual Civil 
(2015)

Collins, Kristin A. "A Considerable Surgical Operation": Article III, Equity, and Judge-Made Law in the Federal Courts." Duke Law Journal 60, no.2 (2010): 249-343.

Cohen-Koplin, Klaus. "Equidade e Razão Prática na decisão judicial: Algumas reflexes de Teoria Geral do Direito e de História do Pensamento Juridico." Revista da Faculdade de Direito da UFRGS 28 (2011)

Debruche, Anne-Françoise. "What is "Equity"? Of Comparative Law, Time Travel and Judicial Cultures." Revue générale de Droit 39, no.1 (2009): 203-228. https://doi.org/10.7202/1026985ar

de Freitas, Lúcia Gonçalves. "The STF Decision on Abortion of Anencephalic Fetus: A Feminist Discourse Analysis." Alfa: Revista de Linguistica (São José do Rio Preto) 62, no.1 (2018):11-34 https://doi.org/10.1590/1981-5794-1804-1

Gomes, Lucas Alves Edmundo. "The Influences of Common Law on the Brazilian New Code of Civil Procedure." International Journal of Legal Information 46, $\quad$ no. $\quad 3 \quad$ (2018): 180 https://doi.org/10.1017/jli.2018.39

Rosevear, Evan. "Social Rights Interpretation in Brazil and South Africa (Interpretação de direitos sociais no Brasil e na África do Sul)." Revista de Investigações Constitucionais 5, no. 3 (2018): 149-183 http://dx.doi.org/10.5380/rinc.v5i3.60968

Wambier, Teresa Arruda Alvim and Cassio Scarpinella Bueno. "Civil Justice in Bazil." Brics Law Journal 3, no. 4 (2016): 6-40. https://doi.org/10.21684/2412-2343-2016-3-4-6-40

\section{Legal Documents}

Brasil. Constituição (1988). Constituição da República Federativa do Brasil. Brasil. Decreto-Lei no 4.657 de 4 de setembro de 1942. Lei de Introdução às normas do Direito Brasileiro.

Brasil. Lei No 5.869 de 11 de janeiro de 1973. Código de Processo Civil.

Brasil. Lei No 10.406 de 10 de janeiro de 2002. Código Civil.

Brasil. Lei No 13105/2015. Novo Código de Processo Civil.

Brasil. Resolution 878/20, Energy Regulatory Agency (ANEEL)

\section{Case Law/Legal Decisions}

Associacao Dos Magistrados Brasileiros. "Coronavirus: confira as decisões do Judiciário relacionadas ao enfrentamento da pandemia." 2020. https://www.amb.com.br/coronavirus-confira-decisoes-do-judiciariorelacionadas-ao-enfrentamento-dapandemia/?doing_wp_cron $=1587890248.6459550857543945312500$

Brazilian Supreme Court. RE 111027, Judging Panel: $2^{\text {nd }}$ Panel Rapporteur: Justice Djaci Falcao, Trial, 1986.

Brazilian Supreme Court. ADPF 54 - Opinion of Justice Carmem Lúcia, Poder Judiciario, Estado Do Rio de Janeiro. "Presidente do TJRJ nega recurso da Light e mantém proibição de corte do fornecimento de 
energia elétrica pelo prazo de 90 dias.” Notícia publicada por Assessoria de Imprensa em 14/04/2020

http://www.tjrj.jus.br/web/guest/home?p_p_id=com_liferay_portal_search_ web_portlet_SearchPortlet\&p_p_lifecycle $=0 \& p \_p \_s t a t e=$ maximized\&p_p_

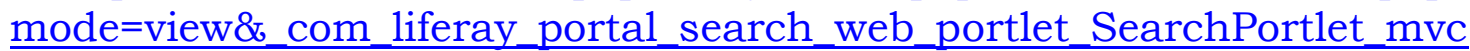
Path=\%2Fview_content.jsp\&_com_liferay_portal_search_web_portlet_Se archPortlet_assetEntryId=7131895\&_com_liferay_portal_search_web_po rtlet_SearchPortlet_type $=$ content\&inheritRedirect $=$ true

RE 271.286 AgR- RS, Rapporteur Justice Celso de Mello

TRF 2 Region. Second Class, AMS 90.02.13999-3. Rio De Janeiro. Judge Luis Alberto Nogueira. 1992.

Tribunal de Justiça do Estado do Rio de janeiro. Appeal. 044875888.2010.8.19.0001. Des. Murilo André Kieling Cardona Pereira -Trial, 2018.

https://www.jusbrasil.com.br/processos/93704262/processo-n-04487588820108190001 -do-tjrj

Tribunal de Justiça do Rio de Janeiro TJ-RJ - Agravo de Instrumento : AI 00189618620208190000 - Inteiro Teor, Des. Sandra Santarém Cardinali, Trial, 2020. https://tjrj.jusbrasil.com.br/jurisprudencia/849228552/agravo-de-instrumentoai-189618620208190000/inteiro-teor-849228565? ref=juris-tabs

\section{Website Content}

Cortez, Frederico. A Nova Justiça Com o COVID-19. Focus.Jor. 20 March 2020. https://www.focus.jor.br/a-nova-justica-com-o-covid-19-porfrederico-cortez/

Mergulhao, Maria Fernanda Dias. "O principio da Equidade: por uma nova exegese." Gen Jurídico, 21 July 2017. http:/ /genjuridico.com.br/2017/07/21/o-principio-da-equidade-poruma-nova-exegese/

Streck, Lenio Luiz and Lúcio Delfino. "Novo CPC e a decisão por equidade: a canabalização do Direito." Consultor Jurídico, 29 December 2015. https://www.conjur.com.br/2015-dez-29/cpc-decisao-equidadecanabalizacao-direito 